\title{
Correlation between hypoxia inducible factor $-1 \alpha$ and renin expression in rats kidney induced by cobalt chloride
}

\author{
Ani R. Prijanti, ${ }^{1}$ Raafqi Ranasasmita, ${ }^{2}$ Yurika Sandra, ${ }^{3}$ Septelia I. Wanandi ${ }^{1}$ \\ ${ }^{1}$ Department of Biochemistry \& Molecular Biology, Faculty of Medicine, Universitas Indonesia, Jakarta, Indonesia \\ ${ }^{2}$ Magister Program, Faculty of Medicine, Universitas Indonesia, Jakarta, Indonesia \\ ${ }^{3}$ Department of Biochemistry, Faculty of Medicine, University of YARSI, Jakarta, Indonesia
}

\begin{abstract}
Abstrak
Latar belakang: Kobalt klorida dapat digunakan sebagai senyawa yang dapat menimbulkan kondisi mimikri hipoksia tanpa kadar rendah oksigen di dalam tubuh, dan menstabilkan hypoxia inducible factor-1 $\alpha$. Kami memutuskan untuk mengobservasi apakah terdapat regulasi ekspresi renin oleh HIF-1 $\alpha$. Dengan demikian kami menyelenggarakan beberapa penelitian untuk memastikan kemungkinan dan memulai dengan penelitian induksi tikus secara intraperitoneal kobalt klorida $\left(\mathrm{CoCl}_{2}\right)$ untuk membangkitkan kondisi mimikri hipoksia dan mendapatkan konsentrasi dan pola ekspresi HIF-1a dan $m R N A$.

Metode: Dua puluh empat ekor tikus dibagi menjadi 4 grup: kontrol, 2, 8, dan 24 jam inkubasi pasca injeksi intraperitoneal $30 \mathrm{mg} / \mathrm{kg}$ berat badan $\mathrm{CoCl}_{2}$. Setelah tikus dikorbankan, organ ginjal digunakan untuk pemeriksaan parameter berat ginjal,

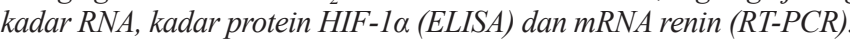

Hasil: Hasil menunjukkan bahwa terdapat perbedaan rasio berat ginjal/berat badan tikus, namun secara statistik tidak bermakna $(p>0,05)$. Secara statistik tidak terdapat perbedaan bermakna kadar protein HIF-1 $\alpha$ antar kelompok $(p>0,05)$. Ekspresi relatif $m R N A$ renin meningkat tajam (30x kontrol), mulai pada 8 jam inkubasi pasca induksi intraperitoneal $\mathrm{CoCl}_{2}$ dan terus meningkat sampai inkubasi 24 jam (2465 x kontrol). Korelasi antara protein HIF-1 $\alpha$ dan ekpresi relatif mRNA renin menggunakan analisis Pearson menunjukkan positif kuat $(R=0,91)(p=0,09)$.
\end{abstract}

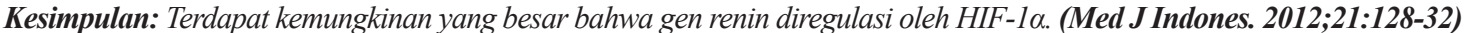

\begin{abstract}
Background: Cobalt chloride can be used as an agent to stabilize hypoxia inducible factor-1 $\alpha$ (HIF-1 $\alpha)$ and to imitate hypoxia without low levels of oxygen inside the body. We intended to investigate if there was any regulation of renin expression by HIF-1 $\alpha$. Therefore, we conducted several studies to clarify this possibility starting with the induction of hypoxic mimicry in rats by intra-peritoneal (IP) injection of cobalt chloride $\left(\mathrm{CoCl}_{2}\right)$ to obtain the levels and pattern of HIF$1 \alpha$ and renin mRNA and protein expression.

Methods: Twenty-four rats were randomly divided into four groups, control group and incubation groups 2, 8, and 24 hours after intra-peritoneal injection of $30 \mathrm{mg} \mathrm{CoCl} 2$ per $\mathrm{kg} \mathrm{BW}$. After the rats were sacrificed, kidneys were excised, weighed and kidney weight compared to BW. Tissue parameters were measured such as RNA concentration, HIF-1 $\alpha$ protein by ELISA, and renin mRNA by RT-PCR.

Results: Differences between the groups in the ratios of kidney weight to BW and in the concentrations of HIF-1 $\alpha$ protein were statistically not significant $(\mathrm{p}>0.05)$. Relative expression of renin mRNA increased markedly starting 8 hours after $\mathrm{CoCl}_{2}$ IP injection (30 times over controls) and further rising until 24 hours ( 2465 times over controls). Correlation between HIF-1 $\alpha$ and renin mRNA by Pearson analysis was strongly positive, but not significant $(R=0.91 ; p=0.09)$.
\end{abstract}

Conclusion: Renin gene regulation in renal hypoxic mimicry strongly correlates with HIF-1 $\alpha$. (Med $\boldsymbol{J}$ Indones. 2012;21:128-32)

Keywords: Cobalt chloride $\left(\mathrm{CoCl}_{2}\right)$, hypoxia inducible factor-1 $\alpha(\mathrm{HIF}-1 \alpha)$, renin

Hypoxia inducible factor (HIF) is a master transcription factor that regulates transcription of several genes to maintain energy homeostasis. ${ }^{1}$ In normoxic condition, HIF- $1 \alpha$ is degraded through ubiqitin-proteasomes. ${ }^{1,2}$ Degradation of HIF-1 begins with the hydroxylation of prolines 402 and 564 in an oxygen-dependentdegradation domain (ODDD) catalyzed by prolylhydroxylase (PHD). ${ }^{2,3}$ Hydroxyprolines 402 and 564 in HIF-1 $\alpha$ are recognized by the tumor suppressor vonHippel-Lindau protein ( $p$ VHL), which acts as an $\mathrm{E}_{3}$ ubiquitin ligase. After ubiqitinylation, HIF-1 $\alpha$ is degraded proteasomally. ${ }^{4}$ In hypoxic condition, lack of oxygen as a PHD co-substrate decreases the enzyme activity and increase HIF-1 $\alpha^{2}$ Prolyl-hydroxylase activity needs the presence of substrates and cosubstrates such as oxygen, 2-oxoglutarate, and vitamin $\mathrm{C}$ to catalyze the reaction, which produces hydoxylated HIF-1 $\alpha$, succinate and $\mathrm{CO}_{2} .{ }^{5}$ Besides lack of oxygen, 2-oxoglutarate analogues and $\mathrm{CoCl}_{2}$ can inhibit prolylhydroxylase. ${ }^{6}$ Intraperitoneal- $\mathrm{CoCl}_{2}$ injection to rats stabilizes HIF- $1 \alpha$ and induces hypoxic mimicry. ${ }^{6}$

Kidney infections lead to the disappearance of blood vessels, which causes ischemia and hypertension. ${ }^{1,7,8}$ Since ischemia can trigger renin secretion, ${ }^{1,7-10}$ we considered that HIF-1 $\alpha$ may regulate renin expression. 
Hence, we investigated renin regulation by HIF-1 $\alpha$ through intra-peritoneal injection of cobalt chloride $\left(\mathrm{CoCl}_{2}\right)$ into the rats to induce hypoxic mimicry and obtain the levels and pattern of HIF- $1 \alpha$ and renin mRNA and protein expression.

\section{METHODS}

\section{Animals}

This experimental animal study was conducted in the Department of Biochemistry and Molecular Biology, Faculty of Medicine, Universitas Indonesia, in 2011 and aimed to observe the levels and pattern of HIF$1 \alpha$ and renin during renal hypoxic mimicry. Twentyfour male Sprague-Dawley rats with 150 - 200 gram of body weight from BALITVET Bogor were divided randomly into four groups of 6 rats each: control group and three $\mathrm{CoCl}_{2}$ treated groups. The treatment was performed by intra-peritoneal injection of $\mathrm{CoCl}_{2}$ (30 $\mathrm{mg} / \mathrm{kg} \mathrm{BW}$ ). Incubation times after induction were 2 , 8 and 24 hours before the rats were sacrificed. After the rats were sacrificed, kidneys were removed and kept in a deep-freezer at $-84^{\circ} \mathrm{C}$ until used. Each kidney was homogenized with a micro-pestle and RNA was isolated using "TriPure DNA RNA protein isolation" kit (Roche 11667165 001, Indonesia). From tissue homogenates we obtained the concentration of HIF$1 \alpha$ protein. The RNA isolates were used in Real Time RT-PCR to measure the relative expression of HIF- $1 \alpha$ and renin. HIF-1 $\alpha$ protein was measured by Western blot. HIF- $1 \alpha$ and renin mRNA relative expression were measured by "iScript ${ }^{\mathrm{TM}}$ One Step RT-PCR with SYBR ${ }^{\circledR}$ Green" kit) (BioRad \# 170-8892, USA).

\section{Sample preparation}

\section{Preparation of kidney homogenate}

$100 \mathrm{mg}$ of kidney tissue were put into $1.7 \mathrm{~mL}$ microtubes, then $0.5 \mathrm{~mL}$ TriPure Isolation Reagent was added. The tissue was homogenized at $15-25^{\circ} \mathrm{C}$ using a micro-pestle. Another aliquote of $0.5 \mathrm{~mL}$ TriPure Isolation Reagent was added to the homogenate, then centrifuged at $12000 \mathrm{~g}$ for 10 minutes. The supernatant was used for measurements.

\section{RNA isolation from kidney tissue}

Total RNA was extracted with TriPure (DNA-RNAprotein) Isolation Reagent (Roche 11667165 001, Indonesia).

Separation: Kidney homogenates were incubated at $15-25^{\circ} \mathrm{C}$ for 5 minutes to ensure that nucleoprotein complexes completely dissociated. Then, $0.2 \mathrm{~mL}$ of chloroform $\left(\mathrm{CHCl}_{3}\right)$ were added, shaken vigorously for 15 seconds and incubated again at $15-25^{\circ} \mathrm{C}$ for $2-15$ minutes. Centrifugation at $12000 \mathrm{~g}$ and $2-8^{\circ} \mathrm{C}$ for 15 minutes separated 3 phases. The clear aqueous phase was on top and contained RNA. Interphase and organic phase at the bottom were colored red and contained DNA and proteins.

Isolation of RNA: The clear phase at the top was moved to another microtube. The residual red phases were stored at $-20^{\circ} \mathrm{C}$. To the clear phase $0.5 \mathrm{~mL}$ isopropanol was added, the microtube closed and 15 times shaken up and down. Subsequently, the samples were incubated for 10 minutes at $25^{\circ} \mathrm{C}$ to precipitate RNA, centrifuged at $12,000 \mathrm{~g}$ at $2^{\circ} \mathrm{C}$ for 10 minutes and the supernatant was discarded. To clean the RNA, one $\mathrm{mL}$ of $75 \% \mathrm{EtOH}$ was added to the precipitate, vortexed and precipitated again by centrifugation at $7500 \mathrm{~g}$ and $2^{\circ} \mathrm{C}$ for 5 minutes. The supernatant was discarded. Subsequently, the precipitate was half-dried to become a semi-dry RNA pellet and re-suspended in $50 \mu \mathrm{L}$ of RNAsefree water containing DEPC (DEPC-treated RNAsefree water). The precipitate was dissolved several times by pipette the solution, and then incubated at $55-60^{\circ} \mathrm{C}$ for 15 minutes.

\section{Measurement of parameters}

\section{Primer design of HIF-1 $\alpha$, renin, and $\beta$-actin genes}

We used Primer-3 program to design the primers of HIF-1 $\alpha$ and renin genes. The respective sequences were obtained from the NCBI Gene Bank with the code (NC_005105.2) for rat HIF-1 $\alpha$ and code (NC_005112) for renin. First, a Bioinformatics in silico search through the NCBI web site found the sequences of renin promoter, TATA box, and the structural renin gene. From this information, we made the design of the forward and reverse primer sequences of the promoter containing the HRE with the Primer-3 program. The primers were used for measurement of mRNA relative expression.

\section{cDNA amplification by Real Time - PCR}

We used iScript One-Step RT-PCR Kit with SYBR Green (BioRad), primers of HIF-1 $\alpha$ and renin, microtubes, RT-PCR tubes, microcentrifuge, single and multichannel micropipettes, and RT-PCR with the CFX program (MiniOpticon BioRad ${ }^{\circledR}$ ) as follow: cDNAs were synthesized in 10 minutes at $50^{\circ} \mathrm{C}$; iScript reverse transcriptase was incubated for 5 minutes at $95^{\circ} \mathrm{C}$. Forty PCR cycles were run for 10 
seconds each at $95^{\circ} \mathrm{C}, 30$ seconds at $59^{\circ} \mathrm{C}$, and 30 seconds at $72^{\circ} \mathrm{C}$. Melting curve analysis: 1 minute at $95^{\circ} \mathrm{C}, 1$ minute at $55^{\circ} \mathrm{C}, 10$ seconds at $55^{\circ} \mathrm{C}$, totally 80 cycles, increasing $0.5^{\circ} \mathrm{C}$ for each cycle. By using RT-PCR the amount of cDNA copies can be determined as quantitative gene expression of HIF$1 \alpha$ or renin. We used aquabidest as negative controls to exclude false positive results. As an external standard gene we used $\beta$-actin gene. Through RTPCR we can obtain efficiency and cycle threshold $(\mathrm{Ct})$ values. Expression of HIF-1 $\alpha$ and renin genes was counted by relative quantification and relative concentration of mRNA was calculated using the Livax formula.

\section{Measurement of HIF-1a by ELISA}

This technique was run using Surveyor ${ }^{\mathrm{TM}}$ Intracellular Human/Mouse Total HIF-1 $\alpha$ Immunoassay (R\&D,SUV1935.). A series of standard solutions was made: $31.25 \mathrm{pg} / \mathrm{mL} ; 62.5 \mathrm{pg} / \mathrm{mL} ; 125 \mathrm{pg} / \mathrm{mL}$; $250 \mathrm{pg} / \mathrm{mL} ; 500 \mathrm{pg} / \mathrm{mL} ; 1000 \mathrm{pg} / \mathrm{mL}$. Reagent diluent 2 was used as blank. One hundred microlitre of blank, standards, and sample homogenates of the kidneys were put into each well of an ELISA microplate, incubated with shaking at room temperature for 2 hours. After incubation, the wells were washed 3 times with $250 \mu \mathrm{L}$ washing buffer. Each well was added with $100 \mu \mathrm{L}$ total HIF-1 $\alpha$ detection antibody at a concentration of $50 \mathrm{ng} / \mathrm{mL}$. Wells were incubated for 2 hours with shaking. After washing wells were added with $100 \mu \mathrm{L}$ streptavidine-HRP $1 / 200$, and incubated for 20 minutes with shaking. After washing, each well was added with $100 \mu \mathrm{L}$ mixture of reagent color A and B at 1:1 ratio. The micro-plate was kept in the dark for 20 minutes, $50 \mu \mathrm{L}$ of stop solution was added and during the next 45 minutes, the absorbance was read with the ELISA reader at wavelength of $450 \mathrm{~nm}$.

\section{RESULTS}

The average ratios between kidney and body weights are shown in table 1.

Table 1. Average kidney-body weight ratios in rats with $\mathrm{CoCl}_{2}$ induced hypoxic mimicry

\begin{tabular}{ccc}
\hline Rat groups & $\begin{array}{c}\text { Right kidney } \\
\pm \mathrm{SD}(\%)\end{array}$ & $\begin{array}{c}\text { Left kidney } \\
\pm \mathrm{SD}(\%)\end{array}$ \\
\hline Control & $0.36 \pm 0.04$ & $0.35 \pm 0.04$ \\
2 hours & $0.39 \pm 0.02$ & $0.37 \pm 0.03$ \\
8 hours & $0.37 \pm 0.05$ & $0.37 \pm 0.03$ \\
24 hours & $0.34 \pm 0.04$ & $0.34 \pm 0.04$ \\
\hline
\end{tabular}

The ratios between kidney and body weights were calculated. There is an increase at 2 hours of incubation, slightly stronger in right than in left kidneys. At 8 hours of incubation weight ratios decrease again to about controls normal with no difference between left and right kidneys. At 24 hours of incubation, the kidney-body weight ratios decrease below controls, equally left and right.

\section{HIF-1 $\alpha$ protein}

HIF-1 $\alpha$ protein concentration increases in the 2 hours incubation group and reaches its peak at 8 hours of incubation (Figure 1). After 24 hours protein concentration is back to control values. Statistically, the differences between groups were not significant $(\mathrm{p}>0.05)$.

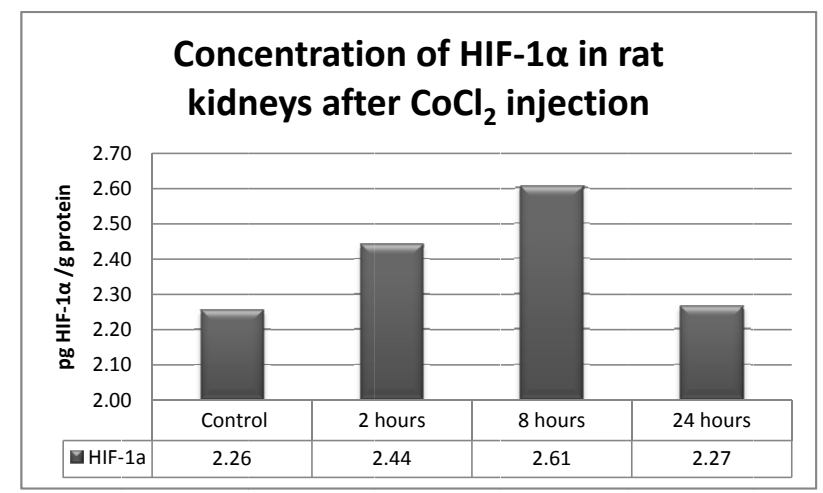

Figure 1. Concentration of HIF-1 $\alpha$ protein in rat kidneys ( $\mathrm{pg} / \mathrm{g}$ tissue protein) after $\mathrm{CoCl}_{2}$ injection

\section{Renin and HIF-1 $\alpha$ mRNA}

HIF-1 $\alpha$ primers were 5'-CTG CCT CTG AAA CTC CAA AGC CAC T-3' (forward) and 5'CTC ACT GGG ACT GTT AGG CTC AGG T-3' (reverse). Renin primers were 5'-CTT TGT ACCGACTTG GGT CA-3' (forward) and 5'-ATT TAG TCT CGT CCC GGA CA-3' (reverse) with a PCR product of $262 \mathrm{bp}$. Primers for the $\beta$-actin reference gene were 5'-ACC ACA GCT GAG AGG GAA ATCG-3' (forward) and 5'-AGA GGT CTT TACGGATGT CAA CG-3' (reverse) with a PCR product of $277 \mathrm{bp}$.

\section{Relative expression of HIF-1a $\mathrm{mRNA}$}

Averages of $\beta$-actin $\mathrm{Ct}$ and HIF-1 $\alpha \mathrm{Ct}$ of rat kidneys induced by $\mathrm{CoCl}_{2}$ are shown in table 2 .

Table 2. Average of HIF-1 $\alpha$ and $\beta$-actin $\mathrm{Ct}$ in rat kidney tissue after $\mathrm{CoCl}_{2}$ injection

\begin{tabular}{ccc}
\hline Rat groups & $\begin{array}{c}\text { Average of } \\
\beta \text {-actin Ct }\end{array}$ & $\begin{array}{c}\text { Average of } \\
\text { HIF- } 1 \alpha \mathrm{Ct}\end{array}$ \\
\hline Control & $27.855 \pm 4.085$ & $24.233 \pm 0.517$ \\
2 hours & $30.883 \pm 1.928$ & $24.294 \pm 2.757$ \\
8 hours & $23.290 \pm 4.680$ & $29.198 \pm 0.794$ \\
24 hours & $27.587 \pm 2.685$ & $29.173 \pm 1.448$ \\
\hline
\end{tabular}




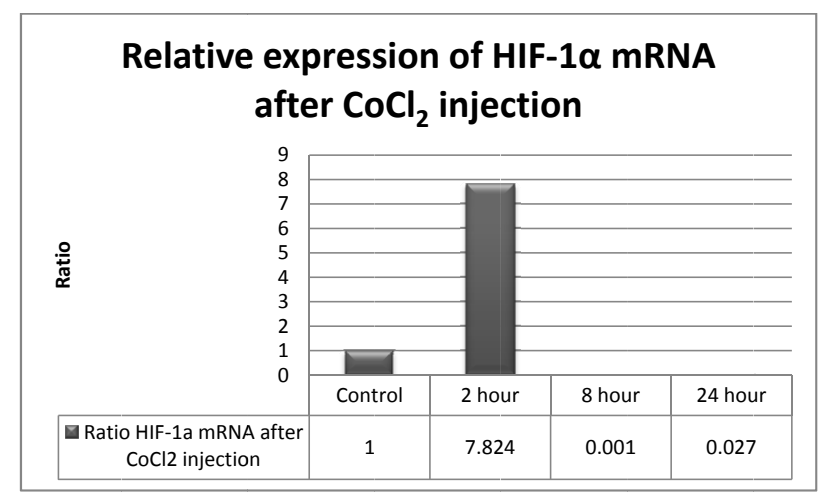

Figure 2. Relative expression of $H I F-1 \alpha m R N A)$ in rat kidneys induced by $\mathrm{CoCl}_{2}$ injection

Relative expression of HIF-1 $\alpha$ increased at 2 hours of incubation after $\mathrm{CoCl}_{2}$ intra-peritoneal injection (7.8 times over controls). In the group of 8 hours incubation after $\mathrm{CoCl}_{2}$ injection $\mathrm{HIF}-1 \alpha$ relative expression was decreased markedly, 1/1000 of controls (Figure 2). In the 24 hours incubation group, HIF- $1 \alpha$ mRNA increased slightly vs. 8 hours, but remained still far below the control group $(27 / 1000)$.

\section{Renin}

Renin mRNA relative expression starts to increase markedly (30 times over controls) at 8 hours after IP $\mathrm{CoCl}_{2}$ injection and further increase until 24 hours (2465 times over controls; figure 3).

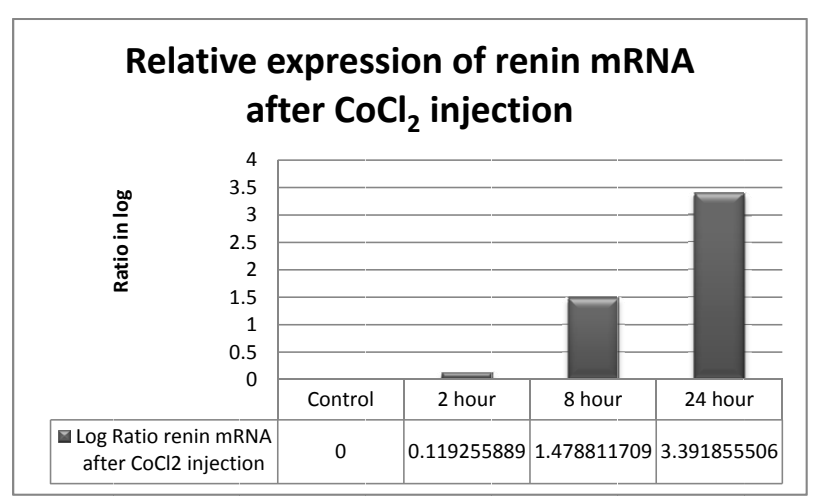

Figure 3. Relative expression of renin $m R N A$ (in logarithmic scale) in rat kidneys induced by $\mathrm{CoCl}_{2}$ injection

Correlation between HIF-1 $\alpha$ protein and renin mRNA by Pearson analysis was strongly positive $(\mathrm{R}=0.91)$ $(\mathrm{p}=0.09)$ (Figure 4).

\section{DISCUSSION}

HIF- $1 \alpha$ is synthesized but the stability of protein is regulated by its degradation process. ${ }^{9}$ The key step of HIF-1 $\alpha$ degradation process is PHD activity that can be modulated by oxygen, cobalt chloride, and desferroxamine..$^{9-11}$ Oxygen is one of the PHD substrates and if enough oxygen is present, PHD hydroxylates prolines of HIF-1 $\alpha$. Subsequently, hydroxylated HIF-1 $\alpha$ will be degraded. Conversely, low oxygen levels in hypoxia inhibit PHD and stabilize HIF-1 $\alpha$. Another regulation of HIF- $1 \alpha$ is on the level of its biosynthesis. ${ }^{9}$ HIF-1 $\alpha$ synthesis can be triggered by activation of $\mathrm{p} 44 / 42 \mathrm{MAPK}$ pathway, a signal transduction pathway through tyrosin kinase and activation of phosphoinositol threephosphate kinase (PI3PK) and mitogen-activating protein kinase (MAPK). MAPK pathway increases the activity of HIF$1 \alpha$ transcription. Morerover, some cytokines such as IL$1 \beta$ and TNF- $\alpha$ can stimulate the binding of HIF- $1 \alpha$ to DNA. The reason why there were no significant different in expression of HIF-1 $\alpha$ protein in oxidative stress and hypoxia is that the process of translation is depressed (suppressed) for energy efficiency., ${ }^{9,11,12}$
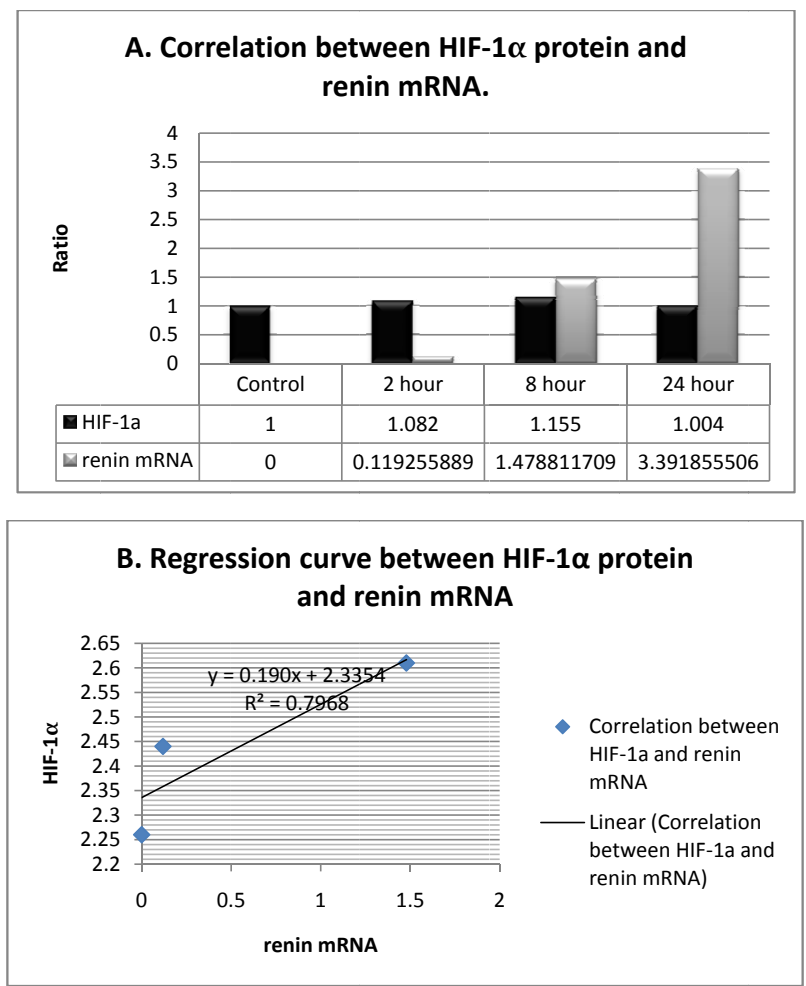

Figure 4. A: Correlation between $H I F-1 \alpha$ protein and renin $m R N A$ in kidney tissue induced by IP $\mathrm{CoCl}_{2}$ injection isstrongly positive (Pearsson correlation 0.91; $p$ $=0.09) ; B$ : Regression curve of HIF-1 $\alpha$ protein and renin $m R N A$

In this research, we saw that renin gene was regulated by HIF- $1 \alpha$ as we had seen in our previous research. ${ }^{10}$ It was already known that HIF- $1 \alpha$ is an acute response to hypoxic condition or to hypoxic mimicry induced by $\mathrm{CoCl}_{2}$, besides renin is the following response to repair kidney homeostasis. Kidney respond to $\mathrm{CoCl}_{2}$ quickly increased HIF$1 \alpha$ and followed by increase of renin. Correlation 
between HIF- $1 \alpha$ protein and HIF-1 $\alpha$ mRNA relative expression by Pearson (SPSS 17) was 0.134, which is means the correlation was weakly positive. In other side, correlation between HIF- $1 \alpha$ protein and renin mRNA in control, 2 hour and 8 hour groups by Pearson analysis was strongly positive $(\mathrm{R}=$ 0.91) $(\mathrm{p}=0.09)($ Figure 4$)$.

Renin is a component of the renin-angiotensinaldosteron-system (RAAS). The RAA system plays a role to maintain homeostasis of body fluids and blood pressure. Renin cleaves angiotensinogen to be angiotensin I. Angiotensin I (ANG I) then is cleaved to angiotensin II (ANG II) by angiotensin converting enzyme (ACE). Angiotensin II binds to its receptor at targeted cells and leads to biological actions or effects such as vasoconstriction, increase of vascular volume by increasing sodium and water retention in renal tubules. Until now, 4 types of ANG II receptors have been revealed: $A T_{1} R, A T_{2} R, A T_{3} R$, and $A T_{4} R$. $A T_{1} R$ is the main receptor of $A N G$ II. $\mathrm{AT}_{2} \mathrm{R}$ is only found in fetuses and neonates. The characteristics of $\mathrm{AT}_{3} \mathrm{R}$ and $\mathrm{AT}_{4} \mathrm{R}$ are not yet known. ${ }^{13}$ Recently, Matsuura et $\mathrm{al}^{14}$ proved that $\mathrm{CoCl}_{2}$ induction suppressed $\mathrm{AT}_{1} \mathrm{R}$ expression and thus, biological effects of ANG II. It was considered that mimicry of hypoxia using $\mathrm{CoCl}_{2}$ did not generate hypertension different from hypoxia that causes renin elevation and hypertension. Hypoxia acts as a key role in cardiovascular defects such as systemic or pulmonary hypertension. ${ }^{14-17}$ Kramer et $\mathrm{al}^{15}$ found that acute hypoxia leads to renin mRNA expression and renin activity in the plasma (plasma renin activity/ PRA). The increase of renin expression and PRA leads to hypertension. Kramer suggested that the increase of renin mRNA expression and PRA in acute hypoxia were caused by the increase of catecholamine concentration in circulation. ${ }^{15}$ Our studies found that renin was one of several genes, which are regulated by HIF$1 \alpha$ (in progress of publishing). ${ }^{10}$ The elevation of HIF- $1 \alpha$ increases renin expression. Therefore, in hypoxia or hypoxic mimicry, besides elevation of catecholamines renin elevation is regulated by the increase of HIF- $1 \alpha$ protein.

In this research, we found that in $\mathrm{CoCl}_{2}$ intra-peritoneal induction of rats, there is a strong correlation between the level of HIF-1 $\alpha$ protein and renin mRNA in the kidney tissues. This result is supporting our previous study that renin expression is regulated by HIF- $1 \alpha$. From this research, we conclude that $\mathrm{CoCl}_{2}$ causes an increase of HIF- $1 \alpha$ protein and renin mRNA relative expression.

\section{Acknowledgment}

The authors are thankful to DRPM UI, which has funded this research through Hibah Riset Unggulan UI 2011.

\section{REFERENCES}

1. Nangaku M, Eckardt KU. Hypoxia and the HIF system in kidney disease. J Mol Med. 2007;85:1325-30.

2. Semenza GL. HIF-1 mediates the Warburg effect in clear cell renal carcinoma. J Bioenerg Biomembr. 2007;39:231-4.

3. Webb JD, Coleman ML, Pugh CW. Hypoxia, hypoxiainducible factors (HIF), HIF hydroxylases and oxygen sensing. Cell Mol Life Sci. 2009;66:3539-54.

4. Fedele AO, Whitelaw ML, Peet DJ. Regulation of gene expression by the hypoxia-inducible factors. Mol Interv. 2002;2(4):229-43.

5. Haase VH. Hypoxia-inducible factors in the kidney. Am J Physiol Renal Physiol. 2006;291:F271-81.

6. Yildirim $O$. The effect of vitamin $C$ and cobalt supplementation on antioxidant status in healthy and diabetic rats. African Journal of Biotechnology. 2009;8(19):5053-8.

7. Nangaku M. Chronic hypoxia and tubulointerstitial injury: a final common pathway to end-stage renal failure. J Am Soc Nephrol. 2006;17:17-25.

8. Edckardt K-U, Bernardt WM, Weidermann A, Warnecke C, Rosenberg C, Weisener MS, et al. Role of hypoxia in pathogenesis of renal disease. Kidney Inter. 2005;68:S46-51.

9. Lee JW, Bae SH, Kim SH, Kim KW. Hypoxia inducible factor- $1 \alpha$ (HIF-1 $\alpha)$ : its protein stability and biological function. Exp Mol Med. 2004;36:1-12.

10. Prijanti AR. Peran hypoxia inducible factor-1 $\alpha$ (HIF-1 $\alpha$ ) dalam pengaturan ekspresi renin [Dissertasion]. Fakultas Kedokteran Universitas Indonesia; 2010. Indonesian.

11. Semenza GL, Shimoda LA, Prabhakar NR. Regulation of gene expression by HIF-1 $\alpha$. Chichester: Wiley \& Sons; 2005. p. 2-14.

12. Stroka DM, Burkhardt T, Desbaillets I, Wenger RH, Neil DAH, Bauer C, et al. HIF-1 expressed in normoxic tissue and display an organ-specific regulation under systemic hypoxia. FASEB J. 2001;15:2445-53.

13. Ichihara A, Sakoda M, Karuaci MA, Kaneshiro, Itoh H. Renin, prorenin and the kidney: a new chapter in old saga. J Nephrol. 2009;22:306-11.

14. Matsuura H, Ichiki T, Ikeda J, Takeda K, Miyazaki R, Hashimoto T, et al. Inhibition of prolyl hydroxylase domaincontaining protein downregulates vascular angiotensin II type 1 receptor. Hypertension. 2011;58:386-93.

15. Kramer BK, Ritthaler T, Schweda F, Kees F, Schricker K, Holmer SR, et al. Effects of hypoxia on renin secretion and renal renin gene expression. Kidney Int. 1998;54(Suppl 67):S155-8.

16. Chung JW, Shin JE, Han KW, Ahn JH, Kim YJ, Park JW, et al. Up-regulation of hypoxia inducible factor-1 alpha by cobalt chloride prevents hearing loss in noise exposed mice. Environ Toxicol Pharmacol. 2011;31(1):153-9.

17. Vengellur A, LaPres JJ. The role of hypoxia inducible factor $1 \alpha$ in cobalt chloride induced cell death in mouse embryonic fibroblasts. Toxicol Sci. 2004;82(2):638-46. 